https://doi.org/10.18485/slav_markovic_slobodan.2018.ch1 929 Марковић, Слободан Ж.

\title{
ПРОФ. ДР СЛОБОДАН Ж. МАРКОВИЋ - ЧОВЕК ИНСТИТУЦИЈА
}

Постоје људи који, где год да крену, нешто оставе за собом. Где год да стану, нешто утемеље. Проф. Слободан Ж. Марковић је био један од таквих људи. Изузетних организационих способности и неуморне радиности, челичне воље и ваљевске домишљатости, проф. Марковић је био један од утемељивача и оснивача неких од најважнијих културних установа у Србији у другој половини 20. века. Задужбина „Десанка Максимовић”, Вукова задужбина, Међународни славистички центар на Филолошком факултету. Био је дугогодишњи председник Друштва за српскохрватски језик, Савеза славистичких друштава Југославије, МСЦ-а, представник српске славистике у Међународном комитету слависта, почасни члан ове светске организације слависта, председник Културно-просветне заједнице Србије. У позадини свих ових функција и задужења била је једна мисао, једна идеја. Свест о потреби неговања и што бољег представљања српске културе у свету и хуманистичка посвећеност језику и књизи.

Није случајно што смо уводни део Зборника посвећеном проф. Марковићу почели задужбинама. Оно што човек учини за душу на овом свету остаје му као попутбина за онај свет. И овај Зборник је, својеврсна, задужбина.

Проф. Марковић је Задужбину „Десанка Максимовић”, сведоци смо томе, пазио као своју кућу. Вукова задужбина је била за њега средиште вуковског завета о потреби сабирања свега што је најбоље у српском језику и култури под један кров. Друштво за српски језик је под његовим руководством постало духовно жариште педагошких активности професора Филолошког факултета. Био је доајен и почасни члан МКС-а, чије се мишљење тражило и уважавало.

У свим овим институцијама проф. Марковић је оставио неизбрисивог трага. И био им је посвећен до краја. Само неколико месеци пре одласка прикупљао је грађу за израду једне личне историје Међународног славистичког центра, коју је једино он и могао да напише. Нажалост, ти мемоари нису довршени. Али је довршена драгоцена историја Друштва за српски језик, поводом његове стогодишњице, коју је проф. Марковић 2010. године написао заједно са Босом Милић. 
Не би било претерано рећи да је у свим великим пројектима, крупним подухватима и темељним захватима српске културе у другој половини 20. века, професор Марковић имао мањег или већег удела. Очувао је Задужбину „Десанка Максимовић” под кровом Народне библиотеке и у најгорим временима, утемељио једну од најзначајнијих награда српског песништва, трасирао пројекат критичког издања Сабраних дела Десанке Максимовић, који ће се, старањем Станише Тутњевића и Ане Ћосић Вукић и остварити на размеђи векова. Национална култура му дугује много. Ваљево, још више.

Међу свим овим Професоровим заслугама издвојио бих једну. То је изузетан лични труд професора Марковића да се испуни сан који српска славистика сања још од времена Александра Белића, да се у Београду одржи велики конгрес светске славистике. Професор Марковић се као дугогодишњи српски представник у Међународном комитету слависта лавовски борио да Србија добије подршку за то. И добила ју је. Једногласно. Некако смо се, људски, надали да ће професор Марковић дочекати Конгрес о коме је толико сањао, јер би то било у складу са људском и са божјом правдом. Али, ко смо ми да одлучујемо о томе. Два најзаслужнија човека за историјски успех српске славистике, проф. Богољуб Станковић и проф. Слободан Ж. Марковић, на XVI мећународном конгресу слависта 2018. године у Београду, нажалост, нису са нама. Али су њихове идеје у корену свих наших напора у склопу припреме и практичне реализације овог важног пројекта.

Шта рећи о његовој посвећености Међународном славистичком центру? Можда је најбоље навести део говора самог професора Слободана Ж. Марковића са другог заседања МСЦ-а, из 1972. године, који је одржао у својству првог директора Центра: „Желео бих да овај симпозијум у своме току оживотвори право значење овога појма које је он имао у старих Грка: да буде духовно добро пријатеља, да покаже сву лепоту зближавања људи у раду и у науци."

Проф. Марковић је био професор старог кова. Као професор нових југословенских књижевности, као управник Катедре за српску књижевност, тада за југословенске књижевности, као продекан и декан Филолошког факултета, професор Марковић је много учинио за наш Факултет. Кроз његове руке су прошле генерације студената, према којима је увек имао очински приступ.

Један од најважнијих професионалних сегмената рада проф. Марковића био је усмерен на праћење, промовисање и тумачење књижевности за децу. Као председник управног одбора Змајевих gечјuх иїара, као главни уредник часописа Дешииғсииво, са својим чувеним антологијама српских прича за децу и српских поема за децу, али и као професор 
Књижевности за децу на Филолошком факултету, професор Марковић је остварио изузетне резултате.

И, на крају. Дирљива је била посвећеност Професора завичају и завичајцима. „Моји Ваљевци”, говорио би увек када бисмо водили студенте, младе слависте, на студијску екскурзију у Бранковину. О завичају је мислио и када је, својим књигама и ауторитетом помагао библиотеку у Љигу. Остаће и та библиотека, да живи. И да чува и очува име професора Марковића.

Постоје људи који, где год да крену, нешто оставе за собом. Где год да стану, нешто утемеље. Проф. Марковић је био један од таквих људи. Отуда ће његови унуци, са истинским поносом моћи да носе успомену на његово име.

Бошко Сувајиић, председник Међународног комитета слависта 